\title{
Pandemic policing: Highlighting the need for trauma-informed services during and beyond the COVID-19 crisis
}

Daniel J. Jones*

\begin{abstract}
There has been a move towards trauma-informed services in multiple systems whose services are provided by police, medical doctors, nurses, teachers, and social workers, to name a few. Trauma-informed practices are best described as understanding the psychological and physiological impacts of trauma in a strengths-based framework. This becomes increasingly important in a policing context during the COVID-19 pandemic. The potential for increased intimate partner violence, child abuse, trauma, and other Adverse Childhood Experiences (ACEs) may have implications for years to come that will impact justice systems, health care, and education. Having trauma-informed police services may mitigate this and provide police with the skills to identify and address issues early on to work towards getting the necessary supports to families in need.
\end{abstract}

\section{INTRODUCTION}

There is no doubt that the COVID-19 pandemic has changed the world, and the need to reduce infection by flattening the curve (Laupacis, 2020) has resulted in orders and new legislation to social distance, stay home, and self-isolate as much as possible. It has also resulted in massive job losses and economic crisis (Ichino et al., 2020). With this come multiple stressors that impact families. There are reports worldwide of increased intimate partner violence and concerns about the safety of children in unsafe homes (Abel \& McQueen, 2020; Campbell, 2020). What does this mean for Canadian policing, both during and post pandemic? With increased intimate partner violence, child abuse, and unsafe home environments comes trauma to adult victims, offenders, and an increase in Adverse Childhood Experiences (ACEs). While not everyone who experiences ACEs ends up in the justice system, many people who are incarcerated do have significant childhood trauma (Jones, Bucerius, \& Haggerty, 2019). The impact of ACEs reaches far beyond the justice system. They are a precursor to a myriad of health problems ranging from addiction to cancer. It has been demonstrated that the level of trauma experienced in the formative years seems to set lives down a course that increases the probability of incarceration, unemployment, poverty, mental health, and addictions, much of this beyond their own control due to the brain injury caused by their respective traumas (Merrick et al., 2017; Messina \& Grella, 2016; Finkelhor, Turner, Shattuck, \& Hamby, 2015).

Trauma-informed policing is using a strengths-based approach and understanding the physiological and psychological impacts of trauma from a police operational lens (Bateson, McManus, \& Johnson, 2019). In the Canadian context, there also needs to be particular attention paid to the impact on Indigenous communities, as the need to physically distance and isolate in one's home because of COVID-19 may trigger past trauma from government assimilation strategies such as residential schools. The residential school program was established to assimilate the population by removing Indigenous children from their homes to educate them in colonial schools. In these schools, they were forbidden to practice any and all traditions celebrated by the Indigenous Peoples of Canada. They were also only allowed to speak English or French and were punished, often physically and harshly for speaking their own Indigenous language (Sinclair, 2016). The "Sixties Scoop" was another assimilation policy, where Indigenous children were arbitrarily removed from their homes and adopted by mostly white middle to upperclass families (Regan, 2010). As a result of these assimilation policies, Indigenous children often hid in homes, and were isolated so as not to be detected by authorities (Sinclar, 2016;

Correspondence to: Daniel J. Jones, 9620103 A Avenue, Edmonton, AB T5H OH7. E-mail: dan.jones@edmontonpolice.ca

To cite: Jones, D. J. (2020). Pandemic policing: Highlighting the need for trauma-informed services during and beyond the COVID-19 crisis. Journal of Community Safety and Well-Being, 5(2), 69-72. https://doi.org/10.35502/jcswb.129

@ Author(s) 2020. Open Access. This work is distributed under the Creative Commons BY-NC-ND license. For commercial re-use, please contact sales@sgpublishing.ca.

g PUBLISHING Published by SG Publishing Inc. CSRA Official publication of the Community Safety Knowledge Alliance. 
Regan, 2010). Hence, the experiences of isolation during the pandemic may be triggering for Indigenous peoples and their families who experienced the Residential School System or the "Sixties Scoop." The triggering of past trauma is a key component of complex trauma (Bath, 2008) and may have an impact on police when interacting with individuals in Indigenous communities. This issue will require traumainformed education provided to police officers to be inclusive of Indigenous-specific trauma information. Including the concept of intergenerational trauma as a result of government assimilation policies in the training will ensure that there is no community harm done with trauma-informed policing (Brave Heart, Chase, Elkins ,\& Altschul, 2011; Pihama, 2017). Trauma-informed policing becomes of significant importance as there will be lasting impacts on mental health from the trauma associated with COVID-19 and the world's response to the pandemic (World Health Organization, 2020a). These mental health ramifications will inevitably land on the police for response. The police are often seen in the Canadian context as frontline mental health workers, since many calls for service that police respond to have a mental health component (Shore \& Lavoie, 2019). Being trauma informed, both during and post pandemic, will allow the police a greater understanding of who they are interacting with and how to interact with this community in a more confident manner (Ford, Newbury, Meredith, Evans, \& Roderick, 2019).

\section{DISCUSSION}

The concept of trauma-informed care is based on three pillars, "Safety, Connections and Managing Impulse Control" (Bath, 2008). All frontline service providers and all professionals who have contact with individuals who have experienced trauma can play an important role in the healing process (Bath, 2008, Ko et al., 2008). The police are the entry point into the criminal justice system, and the first two pillars of traumainformed care, Safety and Connections (Bath, 2008), are two areas where the police can thrive in being trauma informed. Working with partner agencies in the community and being able to provide alternatives to arrest is an opportunity for police to be crucial in the role of addressing trauma. Alternatives to arrest and connecting people to the proper resources can make for a safer community (Engel et al., 2019) because it goes to address the root cause of crime rather than just the specific crime itself (Braga \& Weisburd, 2006).

Policing has historically failed to understand the justice client, regardless of whether it is the victim, the offender, or a combination of both (Jones et al., 2019). Policing has traditionally conducted law enforcement business in a manner that has failed to understand the trauma that people have experienced either during the incident at hand or throughout their life course (Bateson et al., 2019). Understanding trauma also leads to understanding vulnerability, and when police are provided with trauma-informed training, they become more confident and better equipped to deal with vulnerable populations (Ford et al., 2019). If police officers are properly trained to understand the impacts of trauma, they will have a greater ability to positively interact with individuals and work to redirect or off-ramp them with alternatives to arrest while reducing crime (Barberi \& Taxman, 2019; Engel et al., 2019). Providing police with the requisite understanding of trauma leads to an increase in compassion on the part of police officers for the people with whom they are interacting, regardless of whether it is an offender or a victim (Ford et al., 2019).

In the current world climate, with the necessity of physical distancing and levels of isolation to flatten the curve on the spread of COVID-19, there have been reports of worldwide increases of intimate partner violence (Campbell, 2020). The evidence on trauma in a post-pandemic society is scarce, due to the rarity of the situation. However, disasters result in spikes in Post Traumatic Stress responses, increased alcohol and drug use, and other mental health crises (Galea, Merchant, \& Lurie, 2020), regardless of whether they are natural (e.g. hurricanes, tsunamis, earthquakes, etc.) or human-initiated mass traumas (terrorist attacks, mass shootings, etc.). The need for trauma-informed response to mitigate the issues arising due to the COVID-19 pandemic is clear, and early intervention strategies with social agencies are required to assist with the impacts (Galea et al., 2020).

How the police in Canada respond to the trauma of COVID-19 will have repercussions for years to come, both positive and negative. Police in Canada are still trying to recover from a fractured relationship with Indigenous Peoples as a result of policing policy and practice during colonization and the Canadian government assimilation policies, including Residential Schools and the "Sixties Scoop" (LeBeuf, 2011; Nettlelbeck \& Smandych, 2010). Trauma-informed policing is a way to rebuild and build trust and legitimacy within communities (Love-Craighead, 2015; Ko et al., 2008) and work towards less incarceration, while making the community safer (Engel et al., 2019). By taking a trauma-informed approach and training police officers in respective departments across the country, police leaders can provide a better and more informed service to citizens (Ford et al., 2019). Ensuring that a portion of this training is also related to the historic trauma of Canadian Indigenous Peoples (Brave Heart et al., 2011, Pihama et al., 2017) will allow for a better policing response to the issues of the current trauma, which may be influenced by the historic trauma.

The need for trauma-informed policing is clear (Bateson et al., 2019; Ko et al., 2008), but equally important is a need to work on changing police culture. Over the past several years, there has arguably been a shift in policing that has made police more militarized and less connected with community (Balko, 2013). There is a history of police arresting to solve a problem. However, in the long run, the decision to arrest can create more problems than it solves (Harmon, 2016). These problems range from increased recidivism of the arrested person, to interruption of treatment that is addressing the root cause, to loss of community and familial supports for the arrestee and increased costs to the tax payer for charges that are often not prosecuted (Harmon, 2016). Arresting our way out of problems has not solved the continuous increase in crime. There is a necessity for problem-oriented policing to address social problems (Braga \& Weisburd, 2006). Crime is often a symptom of greater social and individual issues, and trauma-informed practice is a way to address problems at the root cause of criminal behaviour (Bateson et al., 2019, Ko et al., 2008). The necessary shift for police is a need to be more strategic on when to arrest and when to work towards an alternative to arrest (Engel et al., 2019). 
There needs to be a clear understanding of the potential to misuse a trauma-informed approach and ACEs as a predictive tool for future criminality or as an offendermanagement strategy (Bateson et al., 2019). There is a history of police failing to follow evidence-based practice or at times to mould the evidence to fit existing interventions (Kalyal, 2019). In order for this to be successful, it is vital that police leaders are clear about the importance of trauma-informed policing and the necessity to intervene differently with a focus on community safety and wellbeing rather than a focus on arrest and detention. When arrests are used sparingly and there is a focus on offramping offenders whenever possible, there has proven to be a reduction in reoffending and in overall crime statistics (Engel et al., 2019; Braga, 2017).

The critical role of the police in ensuring community safety and well-being must be maintained. At this time there is fear of police abuses of power and disproportionate policing of marginalized populations, with the increased police powers as a result of the pandemic (Luscombe \& McClelland, 2020). This is in part because, as the COVID-19 pandemic hits communities, it impacts the marginalized and vulnerable at greater rates than any other demographic (Luscombe \& McClelland, 2020). The need for trauma-informed policing therefore becomes highlighted, as does the necessity for alternatives to incarceration. When police arrest and incarcerate people, there are impacts to the families and the individual in the best of circumstances - the impacts are now exacerbated by the COVID-19 pandemic. The potential to contract COVID-19 in a prison setting leads to increased fears of incarceration by families of offenders and the incarcerated themselves. Prison settings are ripe for the spread of infection, and prisoners are more likely to be impacted by the Coronavirus (World Health Organization, 2020b; Lofgren, Lum, Horowitz, Madubuowu, \& Fefferman, 2020; Stephenson, 2020). Police control the entry into the criminal justice system and must be strategic in the use of arrests and detention during this pandemic and beyond.

It is necessary to provide training on trauma-informed policing if police organization leaders are to set trauma-informed practice as an operational priority. Training in a time of physical distancing is difficult, but there are several online training programs that will assist with creating traumainformed practice in police organizations. For instance, the Canadian Police Knowledge Network has a course on traumainformed practice that can be completed online.

\section{CONCLUSION}

The COVID-19 pandemic has a multitude of impacts on policing, from increased powers to enforce public health orders to modelling shift schedules to ensure that there is no interruption of police services to the community in the event of police officers becoming infected. This global issue has highlighted the need for trauma-informed policing practice. The impacts of trauma from a global pandemic will put a strain on the mental health of many (Galea et al., 2020). The police need to be armed not only with lethal and lessthan-lethal options on their duty belts, they need to have a clear understanding of who the justice client is. Experiencing trauma does not make an individual an offender, but many people who are incarcerated have a significant amount of trauma (Jones et al., 2019). Having trauma-informed practice woven through the respective police services will result in increased legitimacy (Love-Craighead, 2015), and ensuring that the interventions change as a result of this will reduce crime and make a safer community (Engel et al., 2019; Braga, 2017). The future of policing has a definite need to move away from the arrest-and-detain practice to strategically arresting some and strategically offering alternatives to arrest for others in order to make communities safer (Engel et al., 2019). There will be a follow-up social narrative article with a practical guideline to implement trauma-informed practices into police agencies.

\section{CONFLICT OF INTEREST DISCLOSURES}

The author has no conflicts of interest to declare.

\section{AUTHOR AFFILIATIONS}

*University of Huddersfield West Yorkshire United Kingdom and the Edmonton Police Service, Edmonton, AB.

\section{REFERENCES}

Abel, T., \& McQueen, D. (2020). The COVID-19 pandemic calls for spatial distancing and social closeness: Not for social distancing! International Journal of Public Health, 65, 231

Barberi, D., \& Taxman, F. S. (2019). Diversion and alternatives to arrest: A qualitative understanding of police and substance users' perspective. Journal of Drug Issues, 49(4), 703-717.

Bateson, K., McManus, M., \& Johnson, G. (2019). Understanding the use, and misuse, of adverse childhood experiences (ACEs) in trauma-informed policing. The Police Journal, doi: $10.1177 / 0032258 \times 19841409$.

Bath, H. (2008). The three pillars of trauma-informed care. Reclaiming Children and Youth, 17(3), 17-21.

Balko, R. (2013). Rise of the warrior cop: The militarization of America's police forces. New York, NY: PublicAffairs.

Braga, A. A. (2017). Arrests, harm reduction, and police crime prevention policy. Criminology \& Public Policy 16(2), 369-373.

Braga, A. A., \& Weisburd, D. (2006). Problem-oriented policing: The disconnect between principles and practice. Police Innovation: Contrasting Perspectives, 133-154. doi: 10.1017/ CBO9780511489334.007

Brave Heart, M. Y. H., Chase, J., Elkins, J., \& Altschul, D. B. (2011). Historical trauma among Indigenous peoples of the Americas: Concepts, research, and clinical considerations. Journal of Psychoactive Drugs, 43(4), 282-290.

Campbell, A. M. (2020). An increasing risk of family violence during the COVID-19 pandemic: Strengthening community collaborations to save lives. Forensic Science International: Reports. doi: 10.1016/i. fsir.2020.100089.

Engel, R. S., Worden, R. E., Corsaro, N., McManus, H. D., Reynolds, D., Cochran, H., ... Cherkauskas, J. C. (2019). Implications and recommendations. In The Power to Arrest (pp. 141-162). Springer, Cham.

Finkelhor, D., Turner, H. A., Shattuck, A., \& Hamby, S. L. (2015). Prevalence of childhood exposure to violence, crime, and abuse: Results from the national survey of children's exposure to violence. JAMA Pediatrics, 169(8), 746-754

Ford, K., Newbury, A., Meredith, Z., Evans, J., \& Roderick, J. (2019). An evaluation of the Adverse Childhood Experience (ACE) Informed Approach to Policing Vulnerability Training (AIAPVT) pilot. Public Health Wales. 
Galea, S., Merchant, R. M., \& Lurie, N. (2020). The mental health consequences of COVID-19 and physical distancing: The need for prevention and early intervention. JAMA Internal Medicine. doi: 10.1001/jamainternmed.2020.1562

Harmon, R. A. (2016). Why arrest. Michigan Law Review, 115, 307.

Ichino, A., Calzolari, G., Mattozzi, A., Rustichini, A., Zanella, G., \& Anelli, M. (2020). Transition steps to stop COVID-19 without killing the world economy. VoxEU.org. Retrieved from https://voxeu.org/ article/transition-steps-stop-covid-19-without-killing-world-economy

Jones, D. J., Bucerius, S. M., \& Haggerty, K. D. (2019). Voices of remanded women in Western Canada: A qualitative analysis. Journal of community safety and well-being, 4(3), 44-53.

Kalyal, H. (2019). 'One person's evidence is another person's nonsense': why police organizations resist evidence-based practices. Policing: A Journal of Policy and Practice. doi.org/10.1093/police/pay106

Ko, S. J., Ford, J. D., Kassam-Adams, N., Berkowitz, S. J., Wilson, C., Wong, M., ... Layne, C. M. (2008). Creating trauma-informed systems: Child welfare, education, first responders, health care, juvenile justice. Professional Psychology: Research and Practice, 39(4), 396.

Laupacis, A. (2020). Working together to contain and manage COVID-19. Canadian Medical Association Journal, 192(13), E340-E341. doi: 10.1503/cmaj.200428

LeBeuf, M. E. (2011). The role of the Royal Canadian Mounted Police during the Indian residential school system. Ottawa: Royal Canadian Mounted Police.

Love-Craighead, A. (2015). Building trust through trauma-informed policing. New York: Vera.

Lofgren, E., Lum, K., Horowitz, A., Madubuowu, B., \& Fefferman, N. (2020). The epidemiological implications of incarceration dynamics in jails for community, corrections officer, and incarcerated population risks from COVID-19. medRxiv. doi.org/10.1101/2020.04.08 20058842

Luscombe, A., \& McClelland, A. (2020). Policing the pandemic: Tracking the policing of COVID-19 across Canada. SocArSiv Papers. Retrieved from https://osf.io/preprints/socarxiv/9pn27/
Merrick, M. T., Ports, K. A., Ford, D. C., Afifi, T. O., Gershoff, E. T., \& Grogan-Kaylor, A. (2017). Unpacking the impact of adverse childhood experiences on adult mental health. Child Abuse \& Neglect, 69, 10-19.

Messina, N., and Grella, C. (2006). Childhood trauma and women's health outcomes in a California prison population. American Journal of Public Health 96(10), 1842-1848.

Nettelbeck, A., \& Smandych, R. (2010). Policing Indigenous peoples on two colonial frontiers: Australia's mounted police and Canada's North-West Mounted Police. Australian \& New Zealand Journal of Criminology, 43(2), 356-375.

Pihama, L., Tuhiwai Smith, L., Te Nana, R., Cameron, N., Mataki, T., Skipper, H., ... Southey. K. (2017). Investigating Maori approaches to trauma-informed care. Journal of Indigenous Wellbeing 2(3), 18-31.

Regan, P. (2010). Unsettling the settler within: Indian residential schools, truth telling, and reconciliation in Canada. Vancouver, BC: UBC Press.

Shore, K., \& Lavoie, J. A. (2019). Exploring mental health-related calls for police service: a Canadian study of police officers as 'frontline mental health workers'. Policing: A Journal of Policy and Practice, $13(2), 157-171$.

Sinclair, R. (2016). The Indigenous child removal system in Canada: an examination of legal decision-making and racial bias. First Peoples Child \& Family Review, 17(2), 8-18.

Stephenson, J. (2020, April). COVID-19 pandemic poses challenge for jails and prisons. JAMA Health Forum, 1(4), e200422).

World Health Organization. (2020a, 18 March). Mental health and psychosocial considerations during the COVID-19 outbreak, (No. WHO/2019-nCoV/MentalHealth/2020.11. World Health Organization. Retrieved from https://www.who.int/docs/default-source/ coronaviruse/mental-health-considerations.pdf?sfvrsn=6d3578af_2

World Health Organization. (2020b). Preparedness, prevention and control of COVID-19 in prisons and other places of detention (2020), Interim guidance 15 March 2020. Retrieved from https://www.euro. who.int/en/health-topics/health-determinants/prisons-and-health/ publications/2020/preparedness,-prevention-and-control-of-covid19-in-prisons-and-other-places-of-detention,-15-march-2020 